\title{
New species of the genus Nganasania from Upper Cretaceous of Taymyr (Coleoptera: Cryptophagidae)
}

\section{Новый вид рода Nganasania из верхнего мела Таймыра (Coleoptera: Cryptophagidae)}

\author{
G.Yu. Lyubarsky ${ }^{1}$, E.E. Perkovsky ${ }^{2}$ \\ Г.Ю. Аюбарский ${ }^{1}$, Е.Э. Перковский
}

\footnotetext{
${ }^{1}$ Zoological Museum of Moscow State University, Bol'shaya Nikitskaya str. 6, Moscow, 125009 Russia.

${ }^{2}$ Schmalhausen Institute of Zoology, National Academy of Sciences of Ukraine, Bogdan Khmelnitski str. 15, Kiev, 01601 Ukraine.
}

KEY WORDS: Cryptophagidae, Nganasania, Upper Cretaceous, Taymyr amber, Russia.

КЛЮЧЕВЫЕ СЛОВА: Cryptophagidae, Nganasania, верхний мел, Таймырский янтарь, Россия.

ABSTRACT. Nganasania taymyrica sp.n. Lyubarsky et Perkovsky is described based on a fossil inclusion in Upper Cretaceous Taymyr amber (Russia). The new species differs from fossil Nganasania khetica in shape of pronotum, weakly narrowed anteriorly, in less long elytra, and shorted length of body.

PЕЗЮMЕ. Nganasania taymyrica sp.n. Lyubarsky et Perkovsky sp. n. описана из ископаемого янтаря верхнего мела Таймыра (Россия). Новый вид отличается от ископаемого Nganasania khetica слабо суженой кпереди переднеспинкой, менее длинным надкрыльям и меньшей длиной тела.

\section{Introduction}

The family Cryptophagidae is one of the primary lineages in the superfamily Cucujoidea-Coleoptera, which includes about 30 families. The family has about 60 genera and 600 described species. The Cryptophagidae are distributed in all biogeographic realms. The natural history of the family is described in Leschen [1996, 2010].

Fossil records of Cryptophagidae described so far are scarce. Many recent findings are from Baltic and Rovno amber [Spahr, 1981; Hieke, Pietrzeniuk, 1984; Lyubarsky, Perkovsky, 2010, 2011, 2012, 2013; Perkovsky, Lyubarsky, 2014], and there are some fossil impressions as well [Scudder, 1876, Wickham, 1913, 1914, 1916; Cockerell, 1926; Piton, Theobald, 1935; Zhang, 1989]. Basically, all the finds belong to recent genera Atomaria, Cryptophagus, and Micrambe.

Mesozoic finds are quite rare. First of all, from the Lower Cretaceous of southern China Atomaria cretacea was described [Cai, Wang, 2013]. In this work of Cai \& Wang, there is a brief overview of the fossil Cryptophagidae, including Cenozoic Era. From the Upper Cretaceous of Taimyr Nganasania khetica Zherikhin, 1977 was described [Zherikhin, 1977]. This is a monotypic genus, its relationship with other genera of the family are not established, in the revision of the family [Leschen, 1996] it is not included, so that its position in the family is unclear.

Ponomarenko [1977] presented a general characterization of the Upper Cretaceous beetles. According to him, that time was dominated by Cenozoic forms. The replacement of Mesophytic flora by Caenophytic flora had already occurred, gymnosperms were replaced by angiosperms, so that the reshaping of the beetle fauna had already been completed, although there are some relict groups that appeared on the background of a possible crisis of Upper Cretaceous communities. Now this view dominates, although much more details have been discovered [Wang, Zhang, Jarzembowski, 2013]. The angiosperm radiations provided new food resources and habitats, and had a profound effect on beetles and other insects.

Most fossil insects of the Upper Cretaceous are preserved as carbonaceous compressions on the surface of stones or, more rarely, remains in resins. The fossils preserved in resins allow for a more accurate description of the details of the structure of the Mesozoic beetles, and therefore are of special value.

In this paper, we describe a new fossil belonging to the Cryptophagidae family, from the Late Cretaceous of Taymyr amber (Russia). The finding represents a new species belonging to the genus Nganasania Zherikhin, 1977.

\section{Material and methods}

The specimen studied here was collected from the Upper Cretaceous, Taymyr, Khatanga region. The specimen has been found as an inclusion in the fossil resin (retinitis), by analogy with Baltic amber called amber [Zherikhin, 1977].

Based on the study of collections of the expeditions organized by Paleontological Institute of Academy of 
Sciences of USSR in 1970 and 1971, a number of beetle specimens have been identified from Yantardah: Ptiliidae, Staphylinidae (Micropeplinae, Tachyporinae, Aleocharinae), Cerophytidae (Aphytocerus communis Zher.), Melyridae, Latridiidae (Succinimontia infleta Zher. ), Cryptophagidae (Nganasania khetica Zher.), Melandryiidae (Archixylita zherichini Nikitsky and Pseudohallomenus cretaceus Nikitsky), Mordellidae, and a number of other beetles, tentatively attributed to certain families. Unfortunately, most of the beetles mentioned were badly damaged by castor oil.

Expedition PIN RAS 2012 was collected another 80 $\mathrm{kg}$ of samples including retinitis from Yantardah, among others the inclusion described in this article.

Photographs were taken at the Paleontological Institute, Russian Academy of Sciences (PIN PAS) in Moscow by Alexandr P. Rasnitsyn using a Leica M 165 microscope and Leica DFC 425 camera.

\section{Taxonomical part}

Family Cryptophagidae Kirby, 1837

The specimen belongs to family Cryptophagidae. The specimen has characteristic features of the family: the incomplete epipleuron which extends to the posterior edge of the $1^{\text {st }}$ ventrite, and the length of ventrite 1 which is longer than the other ventrites.

The specimen is partially obscured by the opacities in the resin, so some details of the structure can not be determined. Zherikhin described a new genus Cryptophagidae from the same locality, Taimyr. The genus differs from other genera by arcuate shape of sagittal section, depressions at the base of pronotum absent, lateral pronotal margin unmodified, pronotal carina absent.

\section{Nganasania Zherikhin, 1977 \\ Nganasania taymyrica sp.n. Figs 1-2}

MATERIAL: age, formation and locality. \# 3311/711, 712, $713,714,715,716$. Holotype: Russia, Taymyr, Khatanga region, right bank of Maimechi river, $3 \mathrm{~km}$ above the mouth, Yantardakh mountain, Upper Cretaceous, Coniacean-Santonian stage, Kheta formation. Syninclusion with Diptera: Ceratopogonidae, Chironomidae. The type specimen is stored at the Paleontological Institute

DESCRIPTION. Body unicolorous, testaceus, elytra with elevated pubescence.

Eyes normal, well development, with small facets. Ocular setae absent. The antenna is inserted near eye, the distance between antennal insertions greater than the distance between insertion and eye. Antenna is inserted into small concavity. $1^{\text {st }}$ joint of antenna elongate, cylindrical in shape. $3^{\text {rd }}$ antennomere up to $2 \mathrm{x}$ the length of the $4^{\text {th }}$ antennomere. Antennal club is $3-$ segmented. $9^{\text {th }}$ and $10^{\text {th }}$ antennomeres strongly transverse. $11^{\text {th }}$ antennomere elongate, symmetrical and more or less flattened. Ridge surrounding antennal concavity is absent. Front of head is flattened, boss absent. Frontoclypeal suture is present. Width of labial palpomere 1 greater than that of palpomere 2. Clypeus in the same plane as that of frons.

Pronotum distinctly transverse, parallel-sided, broadest basally. Anterior margin of pronotum straight. Pronotum moderately strongly and rarely punctured, punctures separated by 1.0-1.5 diameters apart from their lateral neighbours.
Side borders visible from above along the entire length, not edged, straight, not serrated, pronotal carina absent. Posterior angles obtuselateral. Base of the pronotum without depression. Sagittal view archlike, with common convexity of pronotum and elytra, pronotum in a total arc with elytra, without decrease. Prosternum short, punctured. Anterior coxae transverse, protruding, very close together, coxal cavities outwardly open.

Shape of tibia parallel-sided. Spurs of tibia are not visible. Tarsal formula 5-5-5. Tarsi without lobes.

Elytra long oval, moderately arched, without elytral depressions, weakly curved at sides, broadest approx. at first third of length, 2.2 times as long as pronotum, 1.2 times as long as broad combined. Surface shining, disorderly and moderately closely punctured, punctuate stria are absent. The punctures in the basal part slightly smaller than those on the pronotal disk, and approximately $1-1.5$ diameters apart from their lateral neighbours on an average. Elytral humeri not toothed. Epipleuron present beyond level of posterior margin of metasternum. Metasternum is long and punctured. Coxal lines absent. Metacoxal cavities are located close to each other.

Length of ventrite 1 longer than each of the remaining ventrites. 5 ventrite arcuate, not lobed.

Length $1.4 \mathrm{~mm}$.

ETYMOLOGY. The specific epithet is derived from the name of the geographic region in which the animal lived.

\section{Discussion}

This new species can be attributed to the extant Cryptophagidae as supported by a combination of several characters: $1^{\text {st }}$ ventrite longer than each of the remaining ventrites, tarsal formula 555, tarsi not lobed [Leschen, 2003]. Epipleuron is present beyond level of posterior margin of $1^{\text {st }}$ ventrite. The latter feature occurs in Erotylidae (Leucohimatium, Macrophagus etc.), and Cryptophagidae (Anitamaria, Tisactia, and Antherophagus). Epipleuron of Catopochrotus and Hypophagus is present beyond level of posterior margin of metasternum.

Nganasania khetica is characterized by epipleuron present beyond level of posterior margin of $1^{\text {st }}$ ventrite, $1^{\text {st }}$ ventrite longer than each of the remaining ventrites.

On these grounds the new species is attributed to Cryptophagidae, Nganasania. This genus was described from the same locality, Khatanga, Yantardakh mountain (Taymyr). Zherikhin [1977] identified the new genus by shape of sagittal view. In particular, the shape of sagittal view differentiates Nganasania from Atomaria. From the standpoint of Zherikhin, Nganasania is closer together with Ootypus. In addition, Nganasania khetica differs from many genera of Atomariinae by shape of scutellum. Scutellum in Atomariinae is transversal, its length equal to the width in Nganasania khetica. However, this feature may vary within a genus (Curelius). Scutellum in Nganasania taymyrica sp.n. is not visible.

On the above grounds the new species was attributed to the genus Nganasania. The new species differs from $N$. khetica by shape of pronotum, which is weakly narrowed anteriorly in the new species, less long elytra, 

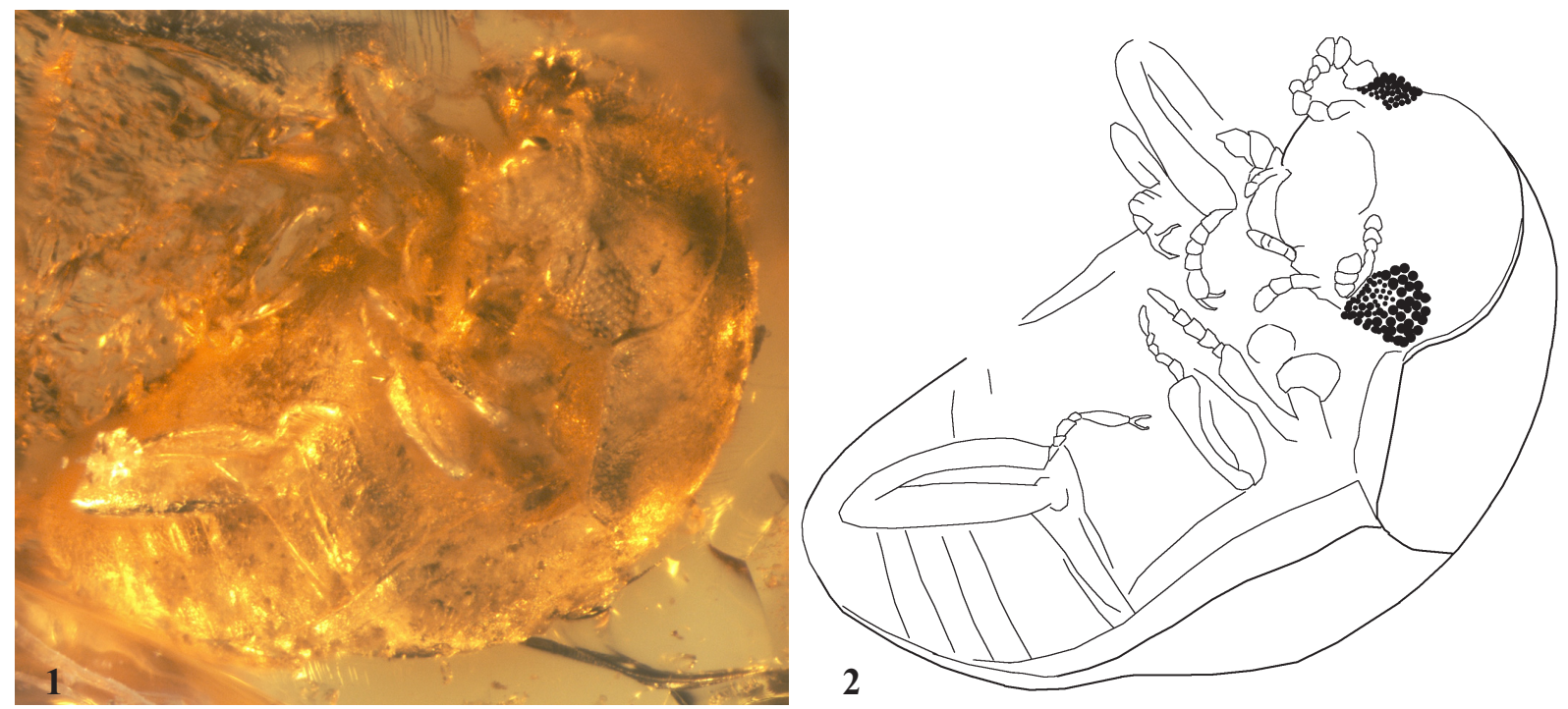

Figs 1-2. Nganasania taymyrica sp.n., holotype: 1 - photo; 2 - line drawings.

Рис. 1-2. Nganasania taymyrica sp.n., голотип: 1 - фотография; 2 - прорисовка.

and smaller length of body. Nganasania khetica has longer elytra, its pronotum is strongly narrowed anteriorly, elytra almost 4 times longer than pronotum, and body length $2 \mathrm{~mm}$. The important common feature of both species of Nganasania is absence of pronotal carina.

Leschen [1996: 556] wrote that this genus had been excluded from his analysis because of the uncertainly of its inclusion in the family based on drawings and illustrations in the original publication. Unfortunately, many important features in our specimen of Nganasania taymyrica are not visible, because of the opacities in amber. Further, it is placed in the extant Atomariinae LeConte, 1861 based on the presence of a distinct frontoclypeal suture.

Nganasania taymyrica sp.n. belongs to the subfamily Atomariinae. Tribe Hypocoprini is characterized by body shape elongate, frons without tubercle, pronotal bead absent, prosternum long in front of coxa, tibia without apical spines. Tribe Cryptafricini characterized by body shape short, oval, frons with tubercle, pronotal bead present, prosternum short in front of coxa, tibia without apical spines. Tribe Atomariini is characterized by body shape short or long, frons without tubercle, pronotal bead present, prosternum short in front of coxa, tibia with apical spines. Nganasania belongs with Atomariini except for one important feature: pronotal bead absent.

A second species is described in the Cretaceous genus Nganasania, the genus can be attributed to the tribe Atomariini.

ACKNOWLEDGEMENTS. The authors express their sincere gratitude to Vyacheslav Martynov (University of Donetsk), to Anatoly Vlaskin (Institute of Zoology, Kiev), and to Ekaterina Sidorchuk (Paleontological Institute, Moscow) for finding and polishing the inclusion, and to Alexandr
Rasnitsyn (Paleontological Institute, Moscow) for kindly taking photographs of the specimen.

\section{References}

Cai C.-Y., Wang B. 2013. The oldest silken fungus beetle from the Early Cretaceous of southern China (Coleoptera: Cryptophagidae: Atomariinae) // Alcheringa. Vol.37. P.452-455.

Cockerell T.D.A. 1926. Some Tertiary fossil insects // Annals and Magazine of Natural History (series 9). Vol.18. P.313-324.

Hieke F., Pietrzeniuk E. 1984. Die Bernstein-Käfer des Museums fur Naturkunde, Berlin (Insecta, Coleoptera) // Mitteilungen aus dem Zoologischen Museum in Berlin. Bd.60. S.297-326.

Leschen R.A.B. 1996. Phylogeny and revision of the genera of Cryptophagidae (Coleoptera: Cucujoidea) // Kansas Science Bulletin. Vol.55. P.549-634.

Leschen R.A.B. 2003. Erotylidae (Insecta: Coleoptera: Cucujoidea): phylogeny and review // Fauna of New Zealand. Vol.47. 108 pp.

Leschen R.A.B. 2010. Cryptophagidae Kirby, 1837 // R.A.B. Leschen, R.G. Beutel, J. F. Lawrence (eds.). Handbook of Zoology. Vol.4. Arthropoda: Insecta. Part 38. Coleoptera, Beetles. Vol. 2. Morphology and Systematics (Elateroidea, Bostrichiformia, Cucujiformia partim). Berlin: Walter de Gruyter. 786 p.

Lyubarsky G. Yu., Perkovsky E.E. 2010. First Eocene species of the genus Micrambe (Cryptophagidae: Coleoptera, Clavicornia) // Vestnik zoologii. Vol.44. No.3. P.275-279.

Lyubarsky G.Yu., Perkovsky E.E. 2011. Third contribution on Rovno amber silken fungus beetles: a new Eocene species of Cryptophagus (Coleoptera, Clavicornia, Cryptophagidae) // ZooKeys. Vol.130. P.255-261.

Lyubarsky G.Yu., Perkovsky E.E. 2012. The first Eocene species of the genus Cryptophagus (Coleoptera, Clavicornia, Cryptophagidae) // Vestnik zoologii. Vol.46. No.1. P.83-87.

Lyubarsky G.Yu. \& Perkovsky E.E. 2013. Fourth contribution on late Eocene amber silken fungus beetles: a new Baltic amber species of Atomaria (Coleoptera, Clavicornia, Cryptophagidae) // Vestnik zoologii. Vol.47. No.3. P.273-276.

Perkovsky E.E., Lyubarsky G.Yu. 2014. Fifth contribution on silken fungus beetles from Late Eocene amber: a second Baltic amber species of Atomaria (Coleoptera: Clavicornia: Cryptophagidae) // Russian Entomological Journal. Vol.23. No.1. P.41-44. 
Piton L.E., Theobald N. 1935. La faune entomologique des gisements miopliocènes du massif central // Revue des Sciences Naturelles d'Auvergne. Vol.1. P.65-104.

Ponomarenko A.G. 1977. [Sostav i ekologycheskaya kharakteristika mezozoiskikh zhestkokrylykh] // Mezozoiskie zhestkokrylye. Trudy paleontologicheskogo instituta. Moscow: Nauka. T.161. P.8-16 [in Russian].

Scudder S.H. 1876. Fossil Coleoptera from the Rocky Mountain tertiaries // Bulletin of the United States Geological and Geographical Surveys of the Territories. Vol.2. P.78-87.

Spahr U. 1981. Systematischer Katalog der Bernstein- und Kopalkäfer (Coleoptera) // Stuttgarter Beiträg. Naturk. (Series B: Geologie und Paläontologie). Bd.80. S.1-107.

Wang B., Zhang H., Jarzembowski E.A. 2013. Early Cretaceous angiosperms and beetle evolution // Frontiers in Plant Science. Vol.4. P.360.
Wickham H.F. 1913. The Princeton collection of fossil beetles from Florissant // Annals of the Entomological Society of America. Vol.6. P.359-366.

Wickham H.F. 1914. New Miocene Coleoptera from Florissant // Bulletin of the Museum of Comparative Zoology, Harvard University. Vol.58. P.423-494.

Wickham H.F. 1916. New fossil Coleoptera from the Florissant beds // Bulletin from the Laboratories of Natural History of the State University of Iowa. Vol.7. P.3-20.

Zhang J.-F. 1989. [Fossil Insects from Shanwang, Shandong, China]. Jinan: Shandong Science and Technology Publishing House. 459 pp. [in Chinese with English summary].

Zherikhin V.V. 1977. [Family Cryptophagidae] // Mezozoiskie zhestkokrylye. Trudy paleontologicheskogo institute. Moscow: Nauka. T.161. P.138-139 [in Russian]. 